\title{
Analisis Peraturan Pemerintah Nomor 23 Tahun 2018: Sudut Pandang Pelaku UMKM
}

\author{
${ }^{1 *}$ Prima Bayu Prakosa, ${ }^{2}$ Amir Hidayatulloh \\ ${ }^{1,2}$ Fakultas Ekonomi dan Bisnis, Universitas Ahmad Dahlan, Indonesia \\ *Email korenpondensi: primabayup@gmail.com
}

\begin{abstract}
This research was conducted to determine the effectiveness of final tax enforcement for MSME entrepreneurs in terms of tax collection principles and to find out the obstacles faxed by MSME entrepreneurs in implementing the final tax. This research is a qualitative study. The analysis of the determination of final income tax base on government regulation number 23 in 2018 provides an explanation of the phenomenon of imposing final tax on MSME. Data collection techniques used were interviews, which given to nine Batik MSME in the special regional of Yogyakarta. The next activity is analyzing by linking the real conditions with particular review that used as a review that is used as reference and guide in conducting a study. Base on the analysis, it was found that the majority of taxpayer (nine batik MSME) said that MSME left injustice, lack of legal certainty, lack of efficiency, and lack of pleasure in paying taxes. Obstacles in implementing government regulation number 23 in 2018 include the existence of government policies related to taxation when in a state of loss makes MSME difficult, the payment system that e-billing makes it is difficult for some MSME because the resource person does not master the internet and computerization, legal certainly is unclear and the existence of problem related to financial statements that have not been properly arranged.
\end{abstract}

Keywords: effectiveness, government regulation number 23 in 2018, Tax final, MSME

Saran sitasi: Prakosa, P. B., \& Hidayatulloh, A. (2019). Analisis Peraturan Pemerintah Nomor 23 Tahun 2018: Sudut Pandang Pelaku UMKM. Jurnal Akuntansi dan Pajak, 20(1), 99-108. doi: http://dx.doi.org/10.29040/jap.v20i1.553

DOI: http://dx.doi.org/10.29040/jap.v20i1.553

\section{Pendahuluan}

Pada tahun 2018, pemerintah mengeluarkan peraturan baru yang mengatur mengenai usaha yang diperoleh atau diterima wajib pajak yang memiliki peredaran bruto tertentu. Peraturan tersebut yaitu Peraturan Pemerintah Nomor 23 Tahun 2018. Peraturan ini menggantikan peraturan sebelumnya, yaitu Peraturan Pemerintah Nomor 46 Tahun 2013. Salah satu perbedaan antara Peraturan Pemerintah Nomor 46 tahun 2013 dengan Peraturan Pemerintah Nomor 23 Tahun 2018, yaitu dari sisi tarif mengalami penurunan, yang menurut peraturan lama $1 \%$ menjadi $0,5 \%$ (Peraturan Pemerintah
Nomor 23, 2018); (Peraturan Pemerintah Nomor 46, 2013).

Peraturan Pemerintah Nomor 23 Tahun 2018 memiliki beberapa aturan didalamnya seperti aturan mengenai pihak-pihak yang dikenakan pajak penghasilan final. Pihak-pihak yang dikenakan pajak penghasilan final meliputi orang pribadi, badan berbentuk koperasi, persekutuan, komanditer, firma, dan perseroan terbatas kecuali wajib pajak badan yang memilih untuk dikenakan pajak penghasilan berdasarkan tarif pasal 17 ayat $1 \mathrm{a}$ dan $2 \mathrm{a}$ atau undang-undang 31E pajak penghasilan. Selain itu, wajib pajak badan yang memiliki keahlian khusus dalam 


\section{Jurnal Akuntansi dan Pajak, 20(01), 2019, 100}

menyerahkan jasa sehubungan dengan pekerja bebas, wajib pajak badan yang memiliki fasilitas pajak penghasilan berdasarkan 31A undangundang pajak penghasilan dan Peraturan Pemerintah Nomor 94 tahun 2010. Peraturan Pemerintah Nomor 23 Tahun 2018 juga menetapkan kriteria wajib pajak, yakni pelaku usaha yang memiliki omzet dibawah 4,8 miliar per tahun (Peraturan Pemerintah Nomor 23, 2018).

Alasan pemerintah memperlakukan Peraturan Pemerintah Nomor 23 Tahun 2018 karena peraturan sebelumnya (Peraturan Pemerintah Nomor 46 Tahun 2013) dianggap tidak adil yang berdampak dengan masih banyaknya pelaku usaha yang kesulitan dalam pemenuhan kewajiban administrasi perpajakan. Selain itu, peraturan sebelumnya juga dinilai menyulitkan pelaku usaha. Hal ini karena dasar pengenaan pajak didasarkan pada omset, sehingga memungkinkan pelaku UMKM yang mengalami kerugian tetap harus membayar pajak (Peraturan Pemerintah Nomor 23, 2018). Menurut Prastowo (2018), pemberian insentif pajak bertujuan agar pelaku usaha lebih leluasa untuk mengembangkan usahanya, walaupun pemberian insentif pajak ini akan berdampak pada berkurangnya penerimaan Negara dari sektor pajak khususnya UMKM dalam jangka pendek, yaitu kurang lebih Rp2,5 triliun.

Penerapan Peraturan Pemerintah Nomor 23 Tahun 2018 memberikan manfaat bagi pelaku usaha untuk menjalankan bisnisnya. Peraturan ini memberikan kemudahaan kepada wajib pajak untuk melaksanakan kewajiban perpajakannya. Pemberian jangka waktu tertentu dimaksudkan sebagai pembelajaran bagi wajib pajak untuk menyelenggarakan pembukuan sebelum dikenakan peraturan pajak terbaru. Selain itu, penerapan peraturan ini mendorong masyarakat untuk berperan dalam kegiatan ekonomi formal. Selain itu, pemerintah dapat lebih memberikan keadilan bagi pelaku usaha (Peraturan Pemerintah Nomor 23, 2018).

Penurunan tarif pajak yang dilakukan oleh pemerintah memberikan kemudahaan bagi para pelaku usaha. Beban pajak yang ditanggung oleh para pelaku usaha menjadi lebih kecil dibandingkan beban pajak sebelumnya. Oleh karena itu, pelaku usaha memiliki kemampuan serta kesempatan yang lebih besar untuk melakukan investasi dan mengembangkan usahanya. Oleh karena itu, secara tidak langsung dapat memotivasi para pelaku UMKM untuk mengembangkan usahanya (Prastowo, 2018). Pemberlakuan Peraturan Pemerintah Nomor 23 tahun 2018 diharapkan menjadi reformasi awal untuk sektor perpajakan. Hal ini guna mewujudkan sistem perpajakan yang berkeadilan, berkepastian hukum, tepat dan efisien. Selain itu, penerapan tarif yang rendah juga diharapkan dapat mendorong masyarakat untuk berpartisipasi secara aktif dalam dunia usaha, sehingga penurunan tarif tersebut dapat meningkatkan kepatuhan wajib pajak (Mulyani, 2018).

Penelitian ini terinspirasi dari Yusuf (2016), yang meneliti tentang pengenaan pajak penghasilan final terhadap wajib pajak tertentu yang menggunakan studi kasus pada Usaha Mikro, Kecil, dan Menengah (UMKM) di kecamatan Pancoran Jakarta Selatan. Pemberlakuan penerapan peraturan terbaru yang diterapkan saat ini menjadi salah satu fokus penelitian oleh banyak kalangan. Oleh karena itu, peneliti tertarik melakukan penelitian terkait penerapan Peraturan Pemerintah Nomor 23 Tahun 2018 yang dilihat dari sudut pandang pelaku UMKM. Pelaku UMKM yang menjadi responden dalam penelitian ini adalah pelaku UMKM Batik di Daerah Istimewa Yogyakarta.

Daerah Istimewa Yogyakarta telah menjadi pusat batik di Indonesia dan dengan penobatan tersebut, batik Daerah Istimewa Yogyakarta lebih dikenal oleh dunia. Selain itu, batik juga menjadi salah satu faktor yang menarik wisatawan asing dan lokal untuk berkunjung ke Daerah Istimewa Yogyakarta. Sehingga, UMKM diuntungkan dengan hal tersebut. Situasi tersebut juga berdampak positif bagi pertumbuhan ekonomi di Daerah Istimewa Yogyakarta. Data Bank Indonesia menunjukkan bahwa kinerja 


\section{Jurnal Akuntansi dan Pajak, 20(01), 2019, 101}

perekonomian Daerah Istimewa Yogyakarta berada dalam keadaan yang baik yaitu lebih tinggi di atas perekonomian nasional yaitu sebesar 5,26 persen year on year sedangkan perekonomian Indonesia cenderung stabil di angka 5,07 persen year on year. Begitu juga, dengan data ekspor Daerah Istimewa Yogyakarta. Data ekspor Daerah Istimewa Yogyakarta mengalami pertumbuhan 9,26 persen year on year di tahun 2017 (Mulyani, 2018).

Batik merupakan karya tradisional yang menjadi ciri khas dari Daerah Istimewa Yogyakarta. Batik juga merupakan salah satu ikon Daerah Istimewa Yogyakarta dengan produk-produknya yang dijual sebagai cinderamata. Selain itu, Daerah Istimewa Yogyakarta merupakan Kota batik dunia. Daerah Istimewa Yogyakarta dinobatkan sebagai Kota Batik Dunia pada Oktober Tahun 2014 oleh World Craft Council (WCC) di Dongyang, Provinsi Zhejiang, Tiongkok (Kompas, 2014).

Tahun 2018, pemerintah mengeluarkan peraturan tentang pajak penghasilan dari usaha yang diterima atau diperoleh oleh wajib pajak yang memiliki peredaran bruto tertentu. Peraturan dianggap memberikan kemudahan bagi pelaku usaha dalam menjalankan bisnisnya(Peraturan Pemerintah Nomor 23, 2018). Oleh karena itu, penelitian ini bertujuan untuk menganalisis penerapan Peraturan Pemerintah Nomor 23 Tahun 2018 dari sudut pandang UMKM yang ditinjau dari asas-asas pemungutan pajak, yang meliputi equality, certainly, convenience, economic, and efficiency. Selain itu, penelitian ini juga bertujuan untuk menganalis hambatan-hambatan yang dialami pelaku UMKM dalam menerapkan Peraturan Pemerintah Nomor 23 Tahun 2019.

\section{Metode Penelitian}

Objek penelitian ini adalah UMKM Batik di Daerah Istimewa Yogyakarta. Jenis data dalam penelitian ini adalah data primer. Data primer dalam penelitian ini diperoleh langsung dari pelaku usaha UMKM Batik di Daerah Istimewa
Yogyakarta. Teknik pengumpulan data yang digunakan dalam penelitian ini adalah wawancara. Peneliti melakukan wawancara kepada informan yang berasal dari pemilik UMKM Batik atau unsur pimpinan yang meliputi direktur keuangan, kepala bagian keuangan dibidang perdagangan, maupun manajer UMKM Batik.

Teknik analisis data yang digunakan dalam penelitian ini adalah model interaktif, yang meliputi kegiatan pengumpulan data, reduksi data, penyajian data, penarikan serta pengujuan simpulan (Miles \& Huberman, 1984). Teknik analisis data disajikan pada gambar 1 .

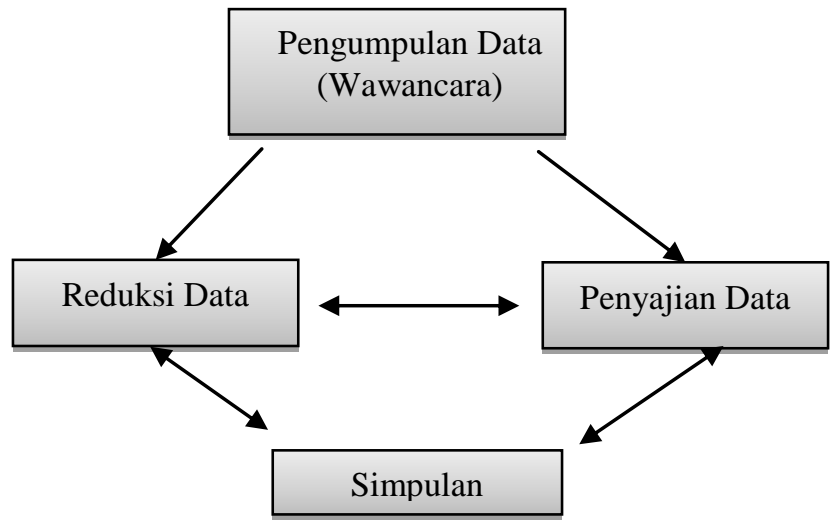

Gambar 1. Teknik Analisis Data

\section{Hasil dan Pembahasan}

Objek penelitian ini adalah sembilan pelaku UMKM Batik. Hasil wawancara dalam penelitian dikaitkan dengan asas pemungutan pajak yang meliputi equality, certainly, convenience, dan economic. Equality artinya pemungutan pajak harus adil dan merata. Certainly artinya dalam pemungutan pajak harus ada kepastian hukum. Convenience artinya pemungutan pajak tidak menyulitkan atau memberatkan, serta economic/efficiency artinya biaya pemungutan pajak harus seminimal mungkin (Smith dalamYusuf, 2016). Hasil analisis untuk masing-masing asas disajikan sebagai berikut.

\subsection{Pemungutan Pajak Ditinjau Dari Asas Keadilan}

Berdasarkan hasil wawancara kepada sembilan pelaku UMKM diperoleh hasil bahwa lima pelaku UMKM menganggap bahwa $\mathrm{PPh}$ final yang saat ini ditetapkan tidak adil. Hal ini 


\section{disebabkan karena karena lima UMKM menganggap kebijakan pemerintah kurang tepat, pemungutan pajak berdasarkan penghasilan bruto, biaya usaha yang dikeluarkan semakin naik karena kenaikan bahan-bahan untuk produksi dan belum jelas laba yang diperoleh. Sedangkan, empat pelaku UMKM menyatakan adil dengan alasan karena tarif yang diterapkan ringan dan perhitungannya mudah. Hasil wawancara dengan pelaku UMKM mengenai asas keadilan disajikan pada tabel 1 .}

\section{Tabel 1.}

Hasil Penelitian Berdasarkan Asas

Keadilan Bagi Wajib Pajak UMK

\begin{tabular}{|c|c|c|}
\hline Kode & Pertanyaan dan Jawaban & Verbatim \\
\hline 01 & $\begin{array}{l}\text { Apakah peraturan }(\mathrm{PPh}) \text { final } \\
0,5 \% \text { yang diterapkan pada } \\
\text { UMKM sudah tepat dan } \\
\text { memberikan keadilan bagi } \\
\text { wajib pajak UMKM? } \\
\text { Jawaban: }\end{array}$ & \\
\hline B & $\begin{array}{l}\text { Aduh mas, agak berat mas } \\
\text { soalnya bahan-bahannya itu } \\
\text { naik ada mori, RST, jadi kita } \\
\text { prihatin lah. Jadi ini kita hanya } \\
\text { mempertahankan. }\end{array}$ & $\begin{array}{l}\text { (Biaya } \\
\text { usaha) }\end{array}$ \\
\hline $\mathrm{C}$ & Belum. Itu kan dari Bruto. & $\begin{array}{c}\text { (Tidak } \\
\text { adil) }\end{array}$ \\
\hline $\mathrm{D}$ & $\begin{array}{l}\text { Ya yang jelas kalo dibilang } \\
\text { adil sih belum mas, karena itu } \\
\text { kan namanya kebyah kebyak } \\
\text { yah, kalo boso indonesia ne } \\
\text { kebyah kebyak opo yo ra } \\
\text { mudeng aku. Intinya begini } \\
\text { seluruh usaha baik itu profit } \\
\text { maupun tidak profit tetap harus } \\
\text { bayar pajak sebesar setengah } \\
\text { pesen. Belum pasti pengusaha } \\
\text { itu untung. }\end{array}$ & $\begin{array}{l}\text { (Laba } \\
\text { kotor) }\end{array}$ \\
\hline $\mathrm{E}$ & $\begin{array}{l}\text { Ya dibilang adil ya adil, ya } \\
\text { pada intinya kita ngk masalah } \\
\text { sih masalah pajak. }\end{array}$ & (Adil) \\
\hline $\mathrm{F}$ & $\begin{array}{l}\text { Menurut saya untuk itu sudah } \\
\text { nganu nggeh, sudah ringan ya } \\
\text { mas ya. }\end{array}$ & (Adil) \\
\hline$G$ & $\begin{array}{l}\text { Allhamdulilah sudah bisa } \\
\text { menurun ya syukur nanti kalo } \\
\text { kita, jujur ya dari laba bersih } \\
\text { gitu. Maunya dari laba bersih } \\
\text { bukan dari laba kotor. }\end{array}$ & $\begin{array}{l}\text { (Kurang } \\
\text { adil) }\end{array}$ \\
\hline $\mathrm{H}$ & Udah mas. & (Adil) \\
\hline
\end{tabular}

\begin{tabular}{|c|l|c|}
\hline Kode & Pertanyaan dan Jawaban & Verbatim \\
\hline I & Ya adil soale lebih murah. & (Adil) \\
\hline J & $\begin{array}{l}\text { Yo ne sebulan yo abot, berarti } \\
\text { kan setaun piro? }\end{array}$ & $\begin{array}{c}\text { Kebera } \\
\text { tan) }\end{array}$ \\
\hline
\end{tabular}

Sumber: wawancara dengan narasumber dan diolah oleh peneliti (2019)

Keterangan: Kode satu adalah pertanyaan saat wawancara, sedangkan B, C, D, E, F, G, H, $\mathrm{I}$, J adalah inisial responden.

\subsection{Pemungutan Pajak Ditinjau Dari Asas Kepastian Hukum}

Menurut hasil wawancara yang telah diperoleh dari sembilan pelaku UMKM, lima pelaku UMKM menyatakan bahwa perubahan peraturan bagi UMKM yang saat ini belum ada kepastian humum. Tiga pelaku UMKM menyatakan sudah memiliki kepastian hukum, sedangkan satu jawaban responden tidak dapat disimpulkan.

Alasan lima responden menyatakan bahwa perubahan peraturan bagi UMKM yang saat ini belum ada kepastian hukum karena pegawai pajak memberikan informasi yang berbeda mengenai Peraturan Pemerintah Nomor 23 Tahun 2018, sehingga pelaku UMKM mengalami kesulitan dan kebingungan untuk menjalankan kebijakan ini. Sedangkan, alasan tiga pelaku UMKM menyatakan sudah ada kejelasan hukum karena Peraturan Pemerintah Nomor 23 Tahun 2018 dianggap memiliki sistem yang baik, prosedur jelas, tata cara jelas, dan tarifnya jelas. Hasil wawancara kepada pelaku UMKM mengenai asas kepastian hukum disajikan pada tabel 2 .

\section{Tabel 2}

Hasil penelitian tentang Asas Kepastian Hukum bagi Wajib Pajak UMKM

\begin{tabular}{|c|c|c|}
\hline Kode & Pertanyaan dan Jawaban & Verbatim \\
\hline 02 & $\begin{array}{l}\text { Beberapa tahun terakhir } \\
\text { pemerintah telah melakukan } \\
\text { perubahan dalam pengaturan } \\
\text { pajak (PPh) bagi pengusaha } \\
\text { UMKM. Apakah dengan } \\
\text { adanya perubahan tersebut, } \\
\text { membuat Bapak/Ibu selaku } \\
\text { wajib pajak memiliki suatu } \\
\text { acuan atau kepastian hukum } \\
\text { perpajakan? }\end{array}$ & \\
\hline
\end{tabular}




\begin{tabular}{|c|c|c|c|c|c|}
\hline \multicolumn{6}{|c|}{ Jurnal Akuntansi dan Pajak, 20(01), 2019, 103} \\
\hline \multirow[t]{2}{*}{ Kode } & \multirow{2}{*}{\multicolumn{2}{|c|}{$\begin{array}{l}\text { Pertanyaan dan Jawaban } \\
\text { Jawaban : }\end{array}$}} & \multirow{2}{*}{\multicolumn{3}{|c|}{$\begin{array}{l}\text { pengenaan PPh final pada UMKM sebesar } 0,5 \% \\
\text { memberikan kemudahaan administrasi dan }\end{array}$}} \\
\hline & & & & & \\
\hline $\mathrm{B}$ & $\begin{array}{l}\text { Iya sudah pasti karena itu } \\
\text { kemaren baru keluar kan } \\
\text { peraturannya dan kita bisa } \\
\text { bayar usahanya. }\end{array}$ & (Pasti) & \multirow{3}{*}{\multicolumn{3}{|c|}{$\begin{array}{l}\text { efektif. Hal ini karena memberikan kemudahaan } \\
\text { administrasi dan kemudahaan dalam } \\
\text { pembayarannya. Sedangkan, tiga pelaku UMKM } \\
\text { menyatakan bahwa pengenaan PPh final pada } \\
\text { UMKM sebesar 0,5\% tidak efektif. Hal ini } \\
\text { disebabkan karena adanya laporan SPT yang } \\
\text { harus dilaporkan tiap tahunnya, serta para pelaku } \\
\text { UMKM kesulitan untuk mengoperasikan e- } \\
\text { billing sehingga membutuhkan bantuan orang } \\
\text { lain untuk mengoperasikannya. Hasil wawancara } \\
\text { kepada pelaku UMKM mengenai asas kepastian } \\
\text { hukum disajikan pada tabel } 3\end{array}$}} \\
\hline $\mathrm{C}$ & $\begin{array}{l}\text { Memberikan jawaban yang } \\
\text { tidak bisa digunakan sebagai } \\
\text { data }\end{array}$ & & & & \\
\hline $\mathrm{D}$ & \multicolumn{2}{|l|}{$\begin{array}{l}\text { Nah kalo yang kepastian } \\
\text { hukumnya ngk anu (jelas) mas, } \\
\text { tapi kalo aturannya ya ya itu } \\
\text { abu-abunya itu dari laba kotor } \\
\text { ada yang bilang ngkpapa di } \\
\text { anu (dikurangi diskon } \\
\text { maksudnya). }\end{array}$} & & & \\
\hline \multirow[t]{2}{*}{$\mathrm{E}$} & \multirow{2}{*}{$\begin{array}{l}\text { Nah itu dia, kepastian } \\
\text { hukumnya itu yang kita belum } \\
\text { tau. Kadang saya sendiri untuk } \\
\text { pelayan hukum masih di ping- } \\
\text { pong sana-sini. }\end{array}$} & \multirow[t]{2}{*}{$\begin{array}{l}\text { (Tidak } \\
\text { jelas) }\end{array}$} & \multicolumn{3}{|c|}{$\begin{array}{l}\text { Tabel } 3 \\
\text { Hasil penelitian tentang Asas Kemudahan } \\
\text { Administrasi bagi Wajib Pajak UMKM }\end{array}$} \\
\hline & & & \multirow{4}{*}{\multicolumn{3}{|c|}{\begin{tabular}{c|l} 
Kode & Pertanyaan dan Jawaban \\
03 & Apakah kebijakan peraturan \\
& PPh final dengan tarif $0,5 \%$ \\
& yang diberlakukan pemerintah \\
& telah memebuat prosedur \\
& administrasi yang dilakukan \\
& menjadi lebih mudah dan \\
efektif? & Jawaban :
\end{tabular}}} \\
\hline $\mathrm{F}$ & $\begin{array}{l}\text { pong sana-sini. } \\
\text { Iya kan itu sudah menjadi } \\
\text { peraturan kan, sudah pasti. }\end{array}$ & (Jelas) & & & \\
\hline G & Ya sudah. & (Jelas) & & & \\
\hline \multirow[t]{3}{*}{$\mathrm{H}$} & \multirow{3}{*}{$\begin{array}{l}\text { Mboten. Ra jelas, ya pokoke } \\
\text { nek prosedure ra podo antara } \\
\text { ini dan ini ngk sama, mumet e } \\
\text { disitu misale podo-podo UKM } \\
\text { batik langsung pasok kan ngk } \\
\text { ada, ngk di kira-kira, } \\
\text { semampune awak e dewe toh } \\
\text { nek nei kan nek digawe } \\
\text { gampang lewih penak lewih } \\
\text { tertib, kenpa dipersulit. } \\
\text { Padahal kita sebagai UKM } \\
\text { udah bener-bener bantu. }\end{array}$} & \multirow[t]{3}{*}{$\begin{array}{l}\text { (Tidak } \\
\text { Jelas) }\end{array}$} & & & \\
\hline & & & $\mathrm{B}$ & Iya mudah. & $\begin{array}{l}\text { (Mudah } \\
\text { dan } \\
\text { Efektif) }\end{array}$ \\
\hline & & & \multirow[t]{2}{*}{$\mathrm{C}$} & \multirow{2}{*}{$\begin{array}{l}\text { Kurang efektif ya mas. Kalo } \\
\text { pembayarannya sederhana, } \\
\text { pelaporannya yang tiap tahun } \\
\text { kan lapor. Itu yang ribet } \\
\text { menurut saya. Kenapa harus } \\
\text { lapor lagi, kan sudah ada, kan } \\
\text { kita bayar tiap bulan }\end{array}$} & \multirow[t]{2}{*}{$\begin{array}{l}\text { (Pelapora } \\
\text { n SPT) }\end{array}$} \\
\hline $\mathrm{I}$ & $\begin{array}{l}\text { Sebenernya kurang dong mas } \\
\text { (kurang paham). Tentang } \\
\text { aturannya itu juga. }\end{array}$ & $\begin{array}{l}\text { (Tidak } \\
\text { jelas) }\end{array}$ & & & \\
\hline $\mathrm{J}$ & $\begin{array}{l}\text { aturannya itu juga. } \\
\text { Kalo kepastian hukumnya aku } \\
\text { belum jelas. }\end{array}$ & $\begin{array}{l}\text { (Tidak } \\
\text { jelas) }\end{array}$ & \multirow[t]{2}{*}{$\bar{D}$} & \multirow{2}{*}{$\begin{array}{l}\text { Bagi kami perusahaan yang } \\
\text { sudah seperti kami ini, efektif } \\
\text { tapi nek mau bilang nyasar ke } \\
\text { bakul pecel lele, bakul soto dan } \\
\text { yang lain-lain mereka kan ngk } \\
\text { bisa, bikin e-biling kan ngk } \\
\text { bisa. }\end{array}$} & \multirow[t]{2}{*}{ (Efektif) } \\
\hline \multirow{4}{*}{\multicolumn{3}{|c|}{$\begin{array}{l}\text { Sumber: wawancara dengan narasumber dan } \\
\text { diolah oleh peneliti (2019) } \\
\text { Keterangan: Kode dua adalah pertanyaan saat } \\
\text { wawancara, sedangkan B, C, D, E, F, G, H, } \\
\text { I, J adalah inisial responden. } \\
\text { 3.3. Pemungutan Pajak Ditinjau Dari Asas } \\
\text { Kemudahan Administrasi } \\
\text { Menurut hasil wawancara yang dilakukan } \\
\text { kepada sembilan pelaku UMKM memperoleh } \\
\text { hasil bahwa enam pelaku UMKM menyatakan }\end{array}$}} & & & \\
\hline & & & $\mathrm{E}$ & $\begin{array}{l}\text { Masih mudah kalo bayar-bayar } \\
\text { mudah mah gitu. }\end{array}$ & (Mudah) \\
\hline & & & $\mathrm{F}$ & $\begin{array}{l}\text { Kalo hanya dihitung dari } \\
\text { persentasi kan lebih mudah, } \\
\text { omsetnya berapa dikalikan iya } \\
\text { kan } 0,5 \text { persen. }\end{array}$ & (Mudah) \\
\hline & & & G & Kalo menurut saya sendiri & (Efektif \\
\hline
\end{tabular}




\begin{tabular}{|c|c|c|}
\hline Kode & Pertanyaan dan Jawaban & Verbatim \\
\hline & $\begin{array}{l}\text { susah, karena jaman sekarang } \\
\text { tidak bisa langsung menerima } \\
\text { itu kan, kalo sekarang kan } \\
\text { harus pake e-biling itu. Untuk } \\
\text { saya sendirri ya karena kita } \\
\text { dibantu anak-anak ya dapat } \\
\text { diatasi tapi kalo saya sendiri ya } \\
\text { saya ngk bisa. Ya kalo dibantu } \\
\text { ya efektif tapi kalo ngk dibantu } \\
\text { ngk bisa jalan sendiri agak } \\
\text { susah. }\end{array}$ & $\begin{array}{c}\text { jika } \\
\text { dibantu) }\end{array}$ \\
\hline $\mathrm{H}$ & $\begin{array}{l}\text { Lebih sulit mas soale suruh } \\
\text { pake e-biling, tapi ya dibantu } \\
\text { karo petugase sebenere. }\end{array}$ & (Susah) \\
\hline I & Lebih mudah. & (Mudah) \\
\hline $\mathrm{J}$ & Masih kurang mas. & $\begin{array}{l}\text { (Kurang } \\
\text { Efektif) }\end{array}$ \\
\hline
\end{tabular}

Sumber: wawancara dengan narasumber dan diolah oleh peneliti (2019)

Keterangan: Kode tiga adalah pertanyaan saat wawancara, sedangkan B, C, D, E, F, G, H, I, J adalah inisial responden

\subsection{Pemungutan Pajak Ditinjau Dari Asas Ekonomi/Efisiensi}

Menurut hasil wawancara kepada sembilan pelaku UMKM sebanyak empat pelaku UMKM menyatakan bahwa pemungutan pajak tidak efisien. Hal ini disebakan karena dasar pengenaan pajak didasarkan pada laba kotor atau pendapatan kotor, sehingga pengenaan pajak yang didasarkan pada penghasilan bruto atau laba kotor dianggap memberatkan pelaku UMKM. Selain itu, pengenaan pajak berdasarkan penghasilan bruto atau laba kotor juga dianggap kurang fair. Penyebab lain pengenaan pajak final ini tidak efisien karena biaya usaha yang mengalami kenaikan karena kenaikan harga bahan produksi, sehingga dengan kenaikan biaya usaha pelaku UMKM merasa terbebani.

Tiga pelaku UMKM menganggap bahwa pemungutan pajak sudah memenuhi asas ekonomi dan efisiensi. Hal ini karena tiga pelaku UMKM menganggap bahwa proses administrasi mudah. Sedangkan, jawaban dua pelaku UMKM tidak dapat diolah lebih lanjut. Hasil wawancara kepada pelaku UMKM mengenai asas ekonomi/efisiensi disajikan pada tabel 4 .
Tabel 4

Hasil penelitian tentang Asas Efisiensi bagi Wajib Pajak UMKM

\begin{tabular}{|c|c|c|}
\hline Kode & Pertanyaan dan Jawaban & Verbatim \\
\hline 04 & $\begin{array}{l}\text { Apakah PPh Final 0,5\% dari } \\
\text { omset yang dihitung setiap } \\
\text { bulan sudah sesuai dengan asas } \\
\text { efisiensi/ekonomi dalam hal } \\
\text { pemungutan pajak? } \\
\text { Jawaban: }\end{array}$ & \\
\hline B & $\begin{array}{l}\text { Iya belum, soalnya nanti kita } \\
\text { lihat catatan-catatannya dulu } \\
\text { (Pengeluaran). Aduh mas, agak } \\
\text { berat mas soalnya bahan- } \\
\text { bahannya itu naik ada mori, } \\
\text { RST, jadi kita prihatin lah. Jadi } \\
\text { ini kita } \\
\text { mempertahankan. }\end{array}$ & $\begin{array}{l}\text { (biaya } \\
\text { usaha) }\end{array}$ \\
\hline $\mathrm{C}$ & Cukup efisien. & $\begin{array}{l}\text { (Cukup } \\
\text { Efisien) }\end{array}$ \\
\hline $\mathrm{D}$ & $\begin{array}{l}\text { Ya ndak si mas, tetapi ya lebih, } \\
\text { kalo bisa dibilang lebih } \\
\text { meringankan dari pada yang } \\
\text { satu persen, tapi ya itu tadi } \\
\text { diitung dari omset (laba kotor) } \\
\text { jadi ngk fair. }\end{array}$ & $\begin{array}{l}\text { (Tidak } \\
\text { Efisien) }\end{array}$ \\
\hline $\mathrm{E}$ & Ya efisien lah. & $(\mathrm{Ef}$ \\
\hline $\mathrm{F}$ & $\begin{array}{l}\text { Memberikan jawaban yang } \\
\text { tidak bisa digunakan sebagai } \\
\text { data }\end{array}$ & \\
\hline G & $\begin{array}{l}\text { Memberikan jawaban yang } \\
\text { tidak bisa digunakan sebagai } \\
\text { data }\end{array}$ & \\
\hline $\mathrm{H}$ & Efisien. & (Efisien) \\
\hline $\mathrm{I}$ & $\begin{array}{l}\text { Ya ngk soale kan kalo dari laba } \\
\text { kotor. }\end{array}$ & $\begin{array}{c}\text { (Tidak } \\
\text { Efisien) }\end{array}$ \\
\hline $\mathrm{J}$ & $\begin{array}{l}\text { Untuk itu omsetnya, ya belum- } \\
\text { belum lah. }\end{array}$ & $\begin{array}{l}\text { (Tidak } \\
\text { Efisien) }\end{array}$ \\
\hline
\end{tabular}

Sumber: wawancara dengan narasumber dan diolah oleh peneliti (2019)

Keterangan: Kode empat adalah pertanyaan saat wawancara, sedangkan B, C, D, E, F, G, H, I, $\mathrm{J}$ adalah inisial responden

\subsection{Pemungutan Pajak Ditinjau Dari Asas Kesederhanaan}

Menurut hasil wawancara, lima pelaku UMKM menyatakan bahwa sistem perpajakan yang dibuat oleh pemerintah sudah memenuhi asas kesederhanaan. Hal ini didukung oleh kemajuan teknologi, sehingga dengan kemajuan teknologi tersebut akan memudahkan segala 
aktivitas para UMKM serta mudah menjalankan sistem perpajakan melalui e-billing. Hal ini karena lima pelaku UMKM sudah mengusai internet dan komputerisasi.

Hasil lain yang diperoleh dalam penelitian ini yaitu sebanyak empat pelaku UMKM menyatakan masih kesulitan dalam menjalankan komputer untuk e-billing. Hal ini karena empat pelaku UMKM tersebut tidak lagi berusia muda. Selain itu, empat pelaku UMKM juga menganggap bahwa pelaporan pajak dengan SPT masih dianggap ribet. Hasil wawancara kepada pelaku UMKM mengenai asas kesederhanaan disajikan pada tabel 5 .

\section{Tabel 5}

Hasil penelitian tentang Asas Kesederhanaan bagi Wajib Pajak UMKM

\begin{tabular}{|c|c|c|}
\hline Kode & Pertanyaan dan Jawaban & Verbatim \\
\hline 05 & $\begin{array}{l}\text { Apakah sistem perpajakan } \\
\text { yang dibuat pemerintah sudah } \\
\text { mencerminkan } \\
\text { kesederhanaan? } \\
\text { Jawaban : }\end{array}$ & \\
\hline B & $\begin{array}{l}\text { Kurang anu, seharusnya itu } \\
\text { pajak harus mudah biar } \\
\text { bayarnya mudah. }\end{array}$ & $\begin{array}{c}\text { (Tidak } \\
\text { sederhana } \\
\text { ) }\end{array}$ \\
\hline $\mathrm{C}$ & $\begin{array}{l}\text { Kalo pembayarannya } \\
\text { sederhana, pelaporannya yang } \\
\text { tiap tahun kan lapor. Itu yang } \\
\text { ribet menurut saya. Kenapa } \\
\text { harus lapor lagi, kan sudah } \\
\text { ada, kan kita bayar tiap bulan. }\end{array}$ & $\begin{array}{c}\text { (Pelapora } \\
\text { n SPT) }\end{array}$ \\
\hline $\mathrm{D}$ & $\begin{array}{l}\text { Iya itu tadi bagi kami yang } \\
\text { sudah mengtahui internet dan } \\
\text { komputerisasi itu sederhana. } \\
\text { Ya kita balikan kalo bakul } \\
\text { kayu, sing ra ngerti internet } \\
\text { kon gawe e-biling suruh } \\
\text { bayar ke bank banyak } \\
\text { keluhan-keluhan seperti itu, } \\
\text { bakul kelontong jualan yang } \\
\text { pecah belah kan itu kena } \\
\text { semua yag termasuk UMKM } \\
\text { itu kena semua yang ada } \\
\text { usahanya seharusnya tetapi } \\
\text { kan praktek di lapangannya } \\
\text { kan tidak. }\end{array}$ & $\begin{array}{c}\text { Sederhan } \\
\text { a) }\end{array}$ \\
\hline $\mathrm{E}$ & Ya sederhana. & $\begin{array}{c}\text { (Sederhan } \\
\text { a) }\end{array}$ \\
\hline $\mathrm{F}$ & Sudah sederhana ya. & $\begin{array}{c}\text { Sederhan } \\
\text { a) }\end{array}$ \\
\hline
\end{tabular}

\begin{tabular}{|c|l|c|}
\hline Kode & \multicolumn{1}{|c|}{ Pertanyaan dan Jawaban } & Verbatim \\
\hline $\mathrm{G}$ & $\begin{array}{l}\text { Ya itu kalo pembayarannya } \\
\text { bisa tapi kalo buka e-bilinge- } \\
\text { biling ngk tau gitu mas. }\end{array}$ & (E-biling) \\
\hline $\mathrm{H}$ & $\begin{array}{l}\text { Sederhana tapi niku sulite } \\
\text { nganggo komputer. }\end{array}$ & $\begin{array}{c}\text { Sederhan } \\
\text { a) }\end{array}$ \\
\hline $\mathrm{I}$ & Ya sederhana. & $\begin{array}{c}\text { Sederhan } \\
\text { a) }\end{array}$ \\
\hline $\mathrm{J}$ & $\begin{array}{l}\text { Iya mas aku masih bingung, } \\
\text { terus apa ya mbok nek UKM } \\
\text { biarkan berkembang dulu lah }\end{array}$ & $\begin{array}{l}\text { (Membin } \\
\text { gungkan) }\end{array}$ \\
\hline
\end{tabular}

Sumber: wawancara dengan narasumber dan diolah oleh peneliti (2019)

Keterangan: Kode lima adalah pertanyaan saat wawancara, sedangkan B, C, D, E, F, G, H, $\mathrm{I}$, $\mathrm{J}$ adalah inisial responden

\subsection{Pemungutan Pajak Ditinjau Dari Asas Kesenangan Dalam Pembayaran Pajak}

Menurut hasil wawancara yang telah dilakukan, diperoleh data bahwa tujuh pelaku UMKM masih merasa keberatan dengan adanya kebijakan yang diterapkan pada saat ini. Hal ini karena tujuh pelaku UMKM diharuskan tetap membayar pajak walaupun keadaan ekonomi sedang lesu ataupun dalam keadaan merugi. Sehingga, keadaan tersebut membuat pelaku UMKM menjadi terbebani dan merasa tidak adil. Oleh karena itu, kebijakan saat ini apabila dijalankan, pelaku UMKM menganggap bahwa ini bukan masalah senang maupun tidak senang akan tetapi lebih dari keterpaksaan.

Dua pelaku UMKM menganggap membayar pajak menyenangkan. Hal ini karena dua pelaku UMKM tersebut menganggap bahwa sebagai warga Negara yang baik maka pelaku UMKM tetap bayar pajak. Hasil wawancara kepada pelaku UMKM mengenai asas kesenangan dalam pembayaran pajak disajikan pada tabel 6 .

Tabel 6

Hasil penelitian tentang Asas Kesenangan bagi Wajib Pajak UMKM

\begin{tabular}{|l|l|l|}
\hline Kode & Pertanyaan dan Jawaban & Verbatim \\
\hline
\end{tabular}

06 Bagaimana Menurut pendapat Bapak/Ibu apabila keadaan ekonomi sedang lesu dan omset penjualan turun apakah pemberlakuan tarif $\mathrm{PPh}$ final bagi wajib pajak UMKM sudah tepat dan mencerminkan asas 


\begin{tabular}{|c|c|c|}
\hline \multicolumn{3}{|c|}{ Jurnal Akuntansi dan } \\
\hline Kode & Pertanyaan dan Jawaban & Verbatim \\
\hline & $\begin{array}{l}\text { kesenangan dalam pembayaran } \\
\text { pajak (convenience of } \\
\text { payment)? } \\
\text { Jawaban: }\end{array}$ & \\
\hline B & $\begin{array}{l}\text { Iya senang ini kan kewajiban } \\
\text { ya mas jadi kita ya senang } \\
\text { tidak senang harus tetap bayar. } \\
\text { Iya, kan ini sudah kewajiban } \\
\text { apa ini anu untuk negara ya, } \\
\text { kan ngk dresulo kalo kaya } \\
\text { listrik naik. }\end{array}$ & (Senang) \\
\hline $\mathrm{C}$ & $\begin{array}{l}\text { Ya itu kalo kita rugi, kan kita } \\
\text { ngk selalu untung, kita harus } \\
\text { bayar itu yang berat. }\end{array}$ & $\begin{array}{c}\text { (Member } \\
\text { atkan) }\end{array}$ \\
\hline $\mathrm{D}$ & $\begin{array}{l}\text { Iya, ya itu bukan seneng ya, yo } \\
\text { opo yo mas? Ya paksaan toh } \\
\text { jadinya, kita jadi keterpaksaan } \\
\text { toh, kita kalo ngk bayar disidik } \\
\text { dan diperiksa dan lain-lain jadi } \\
\text { panjang prosesnya malah kita } \\
\text { ngk jadi jualan kalo seperti itu }\end{array}$ & $\begin{array}{c}\text { (Keterpak } \\
\text { saan) }\end{array}$ \\
\hline $\mathrm{E}$ & $\begin{array}{l}\text { Ya namanya pajak kita taat } \\
\text { pajak kan uang pajak juga } \\
\text { bukan untuk negara, akan } \\
\text { kembali kita juga gitu kan } \\
\text { bukan untuk pemerintah atau } \\
\text { personal gitu. Ya seneng- } \\
\text { seneng aja gitu. }\end{array}$ & $(\mathrm{Se}$ \\
\hline $\mathrm{F}$ & $\begin{array}{l}\text { Untuk yang rugi memang } \\
\text { berat, tapi ya anu nggeh } \\
\text { situasional kan semuanya ngk } \\
\text { rugi juga. Kalo bagi yang rugi } \\
\text { memang pajak jadi berat } \\
\text { karena jadi beban. }\end{array}$ & $\begin{array}{r}\mathrm{Me} \\
\text { ratl }\end{array}$ \\
\hline $\mathrm{G}$ & $\begin{array}{l}\text { Ya menurut kita ya ngk adil } \\
\text { karena usaha kecil, kalo usah } \\
\text { gede ya ngk tau. Ya sebisa } \\
\text { mungkin usaha kecil ya } \\
\text { diringankan karena kan ini } \\
\text { usaha kecil kan gitu. }\end{array}$ & $\begin{array}{c}\text { (Tidak } \\
\text { adil) }\end{array}$ \\
\hline $\mathrm{H}$ & $\begin{array}{l}\text { Belum. Ya sebenernya dari } \\
\text { UMKM ini ya keberatan wong } \\
\text { dari kita ngk ada apa-apanya, } \\
\text { modalnya aja sendiri. }\end{array}$ & $\begin{array}{c}\text { (Keberata } \\
\mathrm{n})\end{array}$ \\
\hline $\mathrm{I}$ & $\begin{array}{l}\text { Ya sebenere } \\
\text { pengrajinnya kalo seumpama } \\
\text { rugi suruh bayar soale } \\
\text { menanggung gaji aja udah } \\
\text { susah apalagi suruh bayar } \\
\text { pajak. Tapi untuk sebagai } \\
\text { warga negara yang baik kan } \\
\text { harus bayar. }\end{array}$ & $\begin{array}{l}\text { (Tidak } \\
\text { senang) }\end{array}$ \\
\hline
\end{tabular}

\begin{tabular}{|c|l|c|}
\hline Kode & Pertanyaan dan Jawaban & Verbatim \\
\hline & $\begin{array}{l}\text { Saya tidak setuju e mas. } \\
\text { Sekarang usaha baru merugi }\end{array}$ & (Tidak \\
usaha lagi berjalan, sekarang \\
gini aku pinjem uang di bank \\
belanja-belanja iki durung \\
payu wes dioyak-oyak kon \\
bayar.
\end{tabular}

Sumber: wawancara dengan narasumber dan diolah oleh peneliti (2019)

Keterangan: Kode enam adalah pertanyaan saat wawancara, sedangkan B, C, D, E, F, G, H, $\mathrm{I}, \mathrm{J}$ adalah inisial responden

\subsection{Hambatan-Hambatan Yang Dihadapi Pelaku UMKM Dalam Menerapakan Peraturan Pemerintah Nomor 23 Tahun 2018}

Menurut hasil wawancara, lima pelaku UMKM menyatakan masih ada masalah atau hambatan dalam penerapan Peraturan Pemerintah Nomor 23 Tahun 2018. Hambatanhambatan tersebut meliputi pengenaan pajak ketika para pelaku UMKM mengalami kerugian, sistem pembayaran yang menggunakan teknologi canggih (e-billing), kepastian hukum yang belum jelas, serta adanya masalah yang terkait dengan laporan keuangan yang belum tertata dengan baik. Sedangkan, empat narasumber menyatakan bahwa penerapan Peraturan Pemerintah Nomor 23 Tahun 2018 tidak ada kesulitan atau hambatan. Hasil wawancara kepada pelaku UMKM mengenai hambatan-hambatan dalam penerapan Peraturan Pemerintah Nomor 23 tahun 2018 disajikan pada tabel 7.

Tabel 7

Hasil penelitian tentang Hambatan-Hambatan dalam Penerapan Peraturan Pemerintah Nomor

23 Tahun 2018 bagi Wajib Pajak UMKM

\begin{tabular}{|c|c|c|}
\hline Kode & Pertanyaan dan Jawaban & Ver \\
\hline 07 & $\begin{array}{l}\text { Hambatan-hambatan apa yang } \\
\text { Bapak/Ibu alami terhadap } \\
\text { pelaksanaan penerapan pajak } \\
\text { penghasilan final untuk } \\
\text { pengusaha UMKM? } \\
\text { Jawaban : }\end{array}$ & \\
\hline B & $\begin{array}{l}\text { Tidak ada mas, ya malah anu } \\
\text { kalo sudah waktunya kita }\end{array}$ & $\begin{array}{c}\text { (Tidak } \\
\text { ada) }\end{array}$ \\
\hline
\end{tabular}




\begin{tabular}{|c|c|c|}
\hline \multicolumn{3}{|c|}{ Jurnal Akuntansi dan } \\
\hline Kode & Pertanyaan dan Jawaban & Verbatim \\
\hline & langsung bayar. & \\
\hline $\mathrm{C}$ & $\begin{array}{l}\text { Ya itu kalo kita rugi, kan kita } \\
\text { ngk selalu untung, kita harus } \\
\text { bayar itu yang berat. }\end{array}$ & $\begin{array}{c}\text { (Member } \\
\text { atkan) }\end{array}$ \\
\hline $\mathrm{D}$ & $\begin{array}{l}\text { Nda sih, sekarang lebih lancar } \\
\text { dari pada dulu, sistem } \\
\text { pembayarannya juga sudah } \\
\text { jarang eror, tidak ada hambatan } \\
\text { yang berarti sih sekarang. }\end{array}$ & $\begin{array}{c}\text { (Tidak } \\
\text { ada) }\end{array}$ \\
\hline $\mathrm{E}$ & $\begin{array}{l}\text { Untuk hambatannya dalam } \\
\text { pembayarannya tidak ada } \\
\text { masalah lah gitu. }\end{array}$ & $\begin{array}{c}\text { (Tidak } \\
\text { ada) }\end{array}$ \\
\hline $\mathrm{F}$ & Ngk ada. & $\begin{array}{l}\text { (Tidak } \\
\text { ada) }\end{array}$ \\
\hline $\bar{G}$ & $\begin{array}{l}\text { Ya itu tadi untuk bayarnya } \\
\text { sendiri susah. }\end{array}$ & (E-biling) \\
\hline $\mathrm{H}$ & $\begin{array}{l}\text { Ya kui loh antara kejelasan } \\
\text { satu dengan yang lainnya itu } \\
\text { ngk sama, jawabane wae ra } \\
\text { podo, carane nyalurke ne wae } \\
\text { ra podo. }\end{array}$ & $\begin{array}{l}(\mathrm{Ke} \\
\mathrm{n} \mathrm{hy}\end{array}$ \\
\hline I & $\begin{array}{l}\text { Kalo sekarang kan harus pake } \\
\text { komputer istilahnya kan harus } \\
e \text {-biling kaya gitu, kalo bagi } \\
\text { saya susah soale ngk iso. Kalo } \\
\text { dulu kan tinggal ngisi mudah } \\
\text { lah kesana jadi kalo sekarang } \\
\text { kan ngk, harus ke } e \text {-biling yang } \\
\text { kemaren itu ke kantor sudah } \\
\text { seneng dibantu kalo sekarang } \\
\text { harus istilahnya sendiri gitu } \\
\text { kan padahal kita ora ngerti } \\
\text { dadine agak susah tapi } \\
\text { sebenere lebih mudah tapi } \\
\text { karena ngk bisa tadi jadi susah. }\end{array}$ & $($ E-biling $)$ \\
\hline $\mathrm{J}$ & $\begin{array}{l}\text { Karena pondasi belum kuat, } \\
\text { contohnya pembukuan masih } \\
\text { amburadul. }\end{array}$ & $\begin{array}{c}\text { (Laporan } \\
\text { Keuangan } \\
\text { ) }\end{array}$ \\
\hline
\end{tabular}

Sumber: wawancara dengan narasumber dan diolah oleh peneliti (2019)

Keterangan: Kode tujuh adalah pertanyaan saat wawancara, sedangkan B, C, D, E, F, G, H, I, J adalah inisial responden

\section{Kesimpulan}

Berdasarkan penelitian yang dilakukan, penelitian ini memperluas penelitian sebelumnya (Yusuf, 2016). Hasil penelitian ini mengungkapkan bahwa penerapan Peraturan Pemerintah Nomor 23 Tahun 2018 masih menimbulkan persepsi yang berbeda dari pelaku UMKM batik di Daerah Istimewa Yogyakarta, khususnya yang terkait dengan asas-asas pemungutan pajak. Menurut Smith dalam Yusuf (2016), asas pemungutan pajak terdiri dari asas keadilan, asas kepastian hukum, asas kemudahan adminitrasi, asas ekonomi/efisien, asas kesederhanaan, serta asas kesenangan dalam membayar pajak.

Asas keadilan, menurut sebagian besar pelaku UMKM mengganggap bahwa penerapan Peraturan Pemerintah Nomor 23 Tahun 2018 sudah adil. Hal ini berdasarkan hasil wawancara yang memperoleh bahwa lima pelaku UMKM menganggap adil. Dari asas kepastian hukum, sebagian besar pelaku UMKM menganggap bahwa Peraturan Pemerintah Nomor 23 Tahun 2018 belum memiliki kepastian hukum. Hal ini didukung adanya pernyataan dari lima pelaku UMKM yang menyatakan bahwa peraturan yang diterapkan saat ini tidak memiliki kepastian hukum.

Penerapan Peraturan Pemerintah Nomor 23 tahun 2018 sudah mencerminkan asas kemudahaan administrasi. Hal ini didukung oleh pernyataan empat pelaku UMKM, penerapan peraturan terbaru mudah dalam proses administrasi. Akan tetapi, penerapan Peraturan Pemerintah Nomor 23 Tahun 2018 menurut sebagaian besar pelaku UMKM tidak efisien. Hal ini didukung oleh empat jawaban pelaku UMKM yang menyatakan bahwa peraturan yang diterapkan saat ini tidak efisien.

Menurut lima pelaku UMKM penerapan Peraturan Pemerintah Nomor 23 Tahun 2018 sudah memenuhi asas kesederhanaan. Akan tetapi, Peraturan pemerintah Nomor 23 Tahun 2018 tidak memenuhi asas kesenangan dalam pembayaran pajak. Hal ini didukung oleh jawaban dari tujuh pelaku UMKM yang menyatakan bahwa pelaku UMKM membayar pajak bukan perkara senang atau tidak senang, akan tetapi lebih dari sebuah keterpaksaan.

Pelaku UMKM dalam menerapkan Peraturan Pemerintah Nomor 23 Tahun 2018 mengalami hambatan atau kesulitan. Hambatan 


\section{Jurnal Akuntansi dan Pajak, 20(01), 2019, 108}

tersebut meliputi (1) pengenaan pajak UMKM yang masih didasarkan pada omset bukan pendapatn netto, (2) pembayaran pajak yang menggunakan e-billing dirasa masih menyulitkan para pelaku UMKM, (3) kepastian hukum yang masih belum jelas karena informasi yang diterima oleh pelaku UMKM berbedabeda, sehingga pelaku UMKM merasa kesulitan dalam memahami dan menjelakan kebijakan tersebut, serta (4) masalah laporan keuangan yang dimiliki oleh UMKM yang kurang tertata dengan baik mengakibatkan UMKM kesulitan dalam membayar pajak.

\section{Ucapan Terima Kasih}

Peneliti mengucapkan terima kasih kepada pelaku UMKM Batik yang berada di Daerah Istimewa Yogyakarta yang sudah berkenan menjadi responden penelitian. Sehingga, penelitian ini dapat terselesaikan dengan baik.

\section{Daftar Pustaka}

Kompas. (2014). Yogyakarta Dipilih Jadi Kota Batik Dunia. Retrieved from https://travel.kompas.com/read/2014/10/22/ 140445527/Yogyakarta.Dipilih.Jadi.Kota.Ba tik.Dunia
Miles, M. B., \& Huberman, A. M. (1984). Qualitative Data Analysis. London: Sage Publications.

Mulyani. (2018). Melihat Detil Aturan Tarif PPh Final Umum 0,5 Persen. Retrieved from https://ekonomi.kompas.com/read/2018/06/2 6/090800326/melihat-detil-aturan-tarif-pphfinal-umkm-0-5-persen

Peraturan Pemerintah Nomor 23. (2018).

Peraturan Pemerintah Nomor 46. (2013).

Prastowo. (2018). Pajak UMKM 0,5 Persen Bisa Dongkrak Kegiatan Bisnis. Retrieved from https://ekonomi.kompas.com/read/2018/06/2 2/214100826/pajak-umkm-0-5-persen-bisadongkrak-kegiatan-bisnis.

Yusuf, M. (2016). Analisis Pengenaan Pajak Penghasilan Final Terhadap Wajib Pajak Tertentu Studi Kasus Pada Usaha Mikro Kecil dan Menengah di Kecamatan Pancoran Jakarta Selatan. Jurnal Lentera Akuntansi, 2(1), 22-42. 